\title{
Environmental impacts of pre/during and post-lockdown periods on prominent air pollutants in France
}

\author{
Hamzaoui Ikhlasse ${ }^{1,2,3}$ (D) Duthil Benjamin ${ }^{3,4} \cdot$ Courboulay Vincent $^{4}$. \\ Medromi Hicham ${ }^{1,2}$
}

Received: 15 September 2020 / Accepted: 11 January 2021 / Published online: 23 January 2021

(c) Springer Nature B.V. 2021

\begin{abstract}
The nationwide lockdown inflicted by the global COVID-19 disease epidemic and imposed during 57 days in France was not immune to fluctuations in atmospheric pollutant concentrations. A whole range of human activities has been suspended Monday 17 March 2020 in all French regions. Since then experiments are progressing to reflect the effectiveness of reduced emissions. In this paper, we looked at variations of pollutants prior to, during and after containment period. In a first step, we proved through experiments on eight air pollutants, how all daily maximum pollutants concentration have decreased during containment phase, apart from the ozone pollutant $\mathrm{O}_{3}$. This Ozone pollutant has indeed increased by $27.19 \%$ during lockdown period and kept growing by $21.35 \%$ as well right after deconfinement. Indeed, the maximum daily concentrations detected in different regions of France, have decreased by $18.18 \%, 37.14 \%, 20.36 \%, 9.28 \%, 44.38 \%, 5.1 \%$ and $44.38 \%$, respectively, for the pollutants $\mathrm{SO}_{2}, \mathrm{NO}_{2}, \mathrm{CO}, \mathrm{C}_{6} \mathrm{H}_{6}, \mathrm{NOX}, \mathrm{PM}_{2.5}$ and $\mathrm{PM}_{10}$. Declining levels of other pollutants, however, were not sustained after deconfinement for $\mathrm{NO}_{2}, \mathrm{NOX}$ and $\mathrm{PM}_{10}$. We have reinforced these findings by classifying each pollutant according to the ATMO and AQI indexes, to better visualize their criticality throughout the three lockdown phases (Pre/During/Post). The family of air pollutant variables with their associated geographical sources was thereafter exploited to justify their approximate contribution to the daily mortality rates associated to COVID-19 across all French regions. However, more thorough study is still in progress to validate this finding. Finally, coming up to the abrupt changes in airborne pollutants experienced in this period, a question about future climate crisis was raised again. Whereby a weighting study has shown the current and very shortterm French scenario (Status-Quo) in view of its current environmental path, the political responses made towards future climate change crisis and French investments done in this sense.
\end{abstract}

Keywords SARS-CoV-2 (COVID-19) - France air pollutants concentrations analysis · Pre/ during and post lockdown periods $\cdot$ Multiple correlations $\cdot$ Scenarios projection

Hamzaoui Ikhlasse

Ikhlasse.h12@gmail.com; ikhlasse.hamzaoui@ensem.ac.ma

Extended author information available on the last page of the article 


\begin{tabular}{|c|c|}
\hline Abbreviations & \\
\hline AQI & Air Quality Index \\
\hline CARA & Chemical Characterization of particles \\
\hline COP & Conference of Parties \\
\hline $\mathrm{C}_{6} \mathrm{H}_{6}$ & Benzene \\
\hline EUGreenDeal & European Green Deal \\
\hline GDP & Gross Domestic Product \\
\hline LCSQA & Central Laboratory for Air Quality Monitoring \\
\hline MERA & Measurement and Evaluation in Rural Areas \\
\hline $\mathrm{NO}_{2}$ & Nitrogen dioxide \\
\hline NOX & Nitrogen oxides \\
\hline $\mathrm{O}_{3}$ & Ozone \\
\hline $\mathrm{PM}_{2.5}$ & Particulate Matter $(<2.5 \mu \mathrm{m})$ \\
\hline $\mathrm{PM}_{10}^{2 .}$ & Particulate Matter $(<10 \mu \mathrm{m})$ \\
\hline RRNES & Rapid Response and Novel Research in Earth Science \\
\hline SARS Cov-2 & Coronavirus / COVID-19 \\
\hline SNBC & National Low-Carbon Strategy \\
\hline $\mathrm{SO}_{2}$ & Sulphur dioxide \\
\hline HFDT & Haut-De-France Death Toll \\
\hline GEDT & Grand-Est Death Toll \\
\hline PDLDT & Pays-De-Loire Death Toll \\
\hline AuvDT & Auvergne Death Toll \\
\hline ProvDT & Provence Death Toll \\
\hline NADT & New Aquitaine Death Toll \\
\hline OcciDT & Occitania Death Toll \\
\hline IDFDT & Ile-De-France Death Toll \\
\hline BourgDT & Bourgogne Death Toll \\
\hline CVDLDT & Centre-Val-De-Loire Death Toll \\
\hline NormDT & Normandy Death Toll \\
\hline
\end{tabular}

\section{Introduction}

Seemingly overnight, the coronavirus SARS-CoV-2 (COVID-19) pandemic dramatically changed the habits of millions of people across 213 countries around the world. France is the 20th most severely affected country, with a current total of more than 194,029 cases for an equivalent population of 65,287,519 habitants (Worldometer 2020). This pandemic was firstly identified in France on 29 February 2020. Up to the end of July 2020, the death toll has reached 30,300 as on 707,239 over the world (Coronavirus Update (Live) 2020). As a result of the very quick contagion speed, the decision of a national lockdown was announced in the evening of Monday 16 March 2020, to establish mandatory lockdown and sanitary measures over a 55-days period, beginning from March 17, 2020 till May 11, 2020. Contrary to its sanitary and economic impacts, COVID-19 had the unique advantage during world' lockdown periods of being on one side environmentally friendly, due to the closure of global industrial and transport activities, which are emissions-intensive. Again, most of these changes in the way we behave have had a sustainable dimension.

In this climatic regard, the France has been among the first catalysts raising the profile of climate change (World Health Organization 2015), a fact that is clearly justified since 
the Paris climate agreement resulted from the 'COP 21' conference (Cop 2018), held on December 4, 2015. COP or "Conference of Parties" is a balanced agreement unanimously signed after intensive negotiations between 195 States and the European Union, to work towards greenhouse gas emissions reduction and consecutively atmosphere temperature reduction. The core "COP 21" challenge is to keep the increase in average temperature below 2 degrees and striving to limit this increase to 1.5 degrees (Skah 2018). As an incentive to facilitate the entry of new partners into the coalition, during the "COP 21 " preparatory process, an agenda of early actions highlighting three main types of co-benefits was proposed. These three main co-benefits rely principally on local carbon emission reduction, the development of a new wave of investments and innovations and revealing prices for some emitters' efforts to serve as their justifications and reputations (de Perthuis and Trotignon 2015). Nevertheless, have promises been kept? Some of the publications already report on the vacuity of this agreement. United States has formalized its decision to withdraw from the Paris Agreement, China continue wishing to stop increasing its emissions by 2030, India gives only one indicator of improvement in its carbon intensity related to its GDP (Furfali 2020). As for other parties, each country calculates their potential emission reductions in accordance with its specific circumstances without following any common reference (Fabert 2016).

While responses to the COVID-19 crisis have been within days and weeks, reactions to climate change crisis remain much less acute (Rosenbloom and Markard 2020). It is during this rapidly spreading pandemic crisis, which is more synchronous across large areas, that nations are beginning to recognize connections between this crisis and that of climate change (Manzanedo and Manning 2020). Many international and national studies have strengthened their efforts regarding the two-way impacts between these both crises. Overall, studies have noticed that nature is healing, and the environment is recharging during lockdown periods. Even more, climate experts have claimed that COVID-19 could trigger the biggest globally fall in carbon emissions since World War Two (Chow 2020). So, has the pandemic really succeeded in pushing individuals and leaders nearer to fighting environmental crisis?

In April 2020, while asking 28,029 individuals around the world, in an Ipsos Mori survey (Ipsos Mori 2020), whether they agreed if the question: climate change would be as serious a crisis as COVID-19 in the long term, only $71 \%$ of world person agreed, while the rest tend to strongly disagree. Some believe the massive disruption in our routines induced by the pandemic, could provide an opportunity to switch towards more sustainable lifestyle, only if leaders mobilize an equivalent response to the climate crisis. On a worldwide scale, the American space agency NASA, recently funded four RRNES projects (Tammineni 2020): where satellite remote sensing will be linked to weather, traffic counts, and other data, to shed light on different environmental, economic and societal impacts of the pandemic.

While at a national level, some recent researches underline the significant correlation between climatic factors, air pollutants and the number of coronavirus cases. While studying lockdown impacts amid COVID-19 pandemic on air quality of Delhi megacity in India (Mahato et al. 2020), about 40-50\% improvement in air quality is highlighted just after four days of lockdown start. Still in Delhi, around 43, 31, 10, and 18\% decreases in $\mathrm{PM}_{2.5}$, $\mathrm{PM}_{10}, \mathrm{CO}$, and $\mathrm{NO}_{2}$ were observed during lockdown period compared to previous years (Sharma et al. 2020a, b). Again, when comparing lockdown period, in the city of Rio de Janeiro in Brazil, with the same period in previous year, $\mathrm{NO}_{2}$ and $\mathrm{CO}$ median values were 24.1-32.9 and 37.0-43.6\% lower (Dantas et al. 2020). In a second direction, it has been shown that climatic factors and air quality indexes are also influencing the number and 
severity of COVID-19 spread. According to a Russian study (Pramanik et al. 2020), temperature seasonality $(29.2 \pm 0.9 \%)$ has the highest contribution for COVID-19 transmission in the humid Russian continental region. Yet in the Italian city Milan, a study (Zoran et al. 2020) proved strong influence of daily averaged ground levels of particulate matter concentrations, positively associated with average air temperature and inversely related to air relative humidity, on COVID-19 cases propagation. On the relationship between Air Quality Index (AQI) and COVID-19 outbreak (Pansini and Fornacca 2020) involving Italy, USA, and China, the level of $\mathrm{CO}$ and $\mathrm{SO}_{2}$ in the air is positively related to the number of infections, and lower air quality is provoking more deaths. This point was also affirmed by another study on 72 cities in China (Wang et al. 2020), where an increase in $\mathrm{PM}_{2.5}$ and $\mathrm{PM}_{10}$ particles in the air leads to higher number of daily COVID-19 infections, while a noteworthy coherence between air quality index, mortality and humility was apparent in Wuhan (Fareed et al. 2020).

The present study analyses variations of some prominent air pollutants in France, in pre/ during and post lockdown periods, using a network of gathered data from LCSQA French laboratory, on which many air quality monitoring stations exist across French regions. Thereafter, a multiple correlation analysis is examined to demonstrate the main nexus between maximum pollutants' concentrations values, with their related original locations and the corresponding COVID-19 death rates per French regions. Finally, after an in-depth analysis of the atmospheric emissions data, this study projects post lockdown results on three possible scenarios revealed through a recent study: the positive, the negative and the status-quo. The core target is to explore what this pandemic could mean for climate change in the current and short-term periods.

\section{The study area and related gathered data}

\subsection{Areas of measurement}

Air pollutant concentrations vary in space and time according to many factors in particular: distribution of emission sources, meteorological/topographical conditions, and population densities around measurement sites. Our study uses measurement data derived from the French Central Air Quality Monitoring Laboratory (LCSQA). In collaboration with 3 partners mentioned in (Fig. 1), today the laboratory is becoming the national reference body required by European directives, to ensure the quality of mechanism's data and their adequacy with European requirements and monitoring needs. The whole mechanism known as the "national calibration chain" has been set up to cover a reliable and durable connection of measurements made by stations' analysers. The laboratory has more than 629 stations across many French regions, designed according to existing regulatory and normative texts. The stations are classified according to siting environments (urban, peri-urban, rural ...), and depending on pollutants given their predominant types of influence (LCSQA 2020). Each station designs sampling points while respecting the necessary appropriate precautions over sources of influence. Once values are measured, their uncertainty analyses are dedicated to the Approved Air Quality Monitoring Associations (AASQA), as depicted in (Fig. 1) to officially establish real-time results.

In our study, we collected daily maximum values for 8 pollutants, in a period ranging from January 2020 to July 2020. All the same, for a total of 213 daily maximum values for each pollutant, we also recorded the sources of their sampling sites. There is a total of 


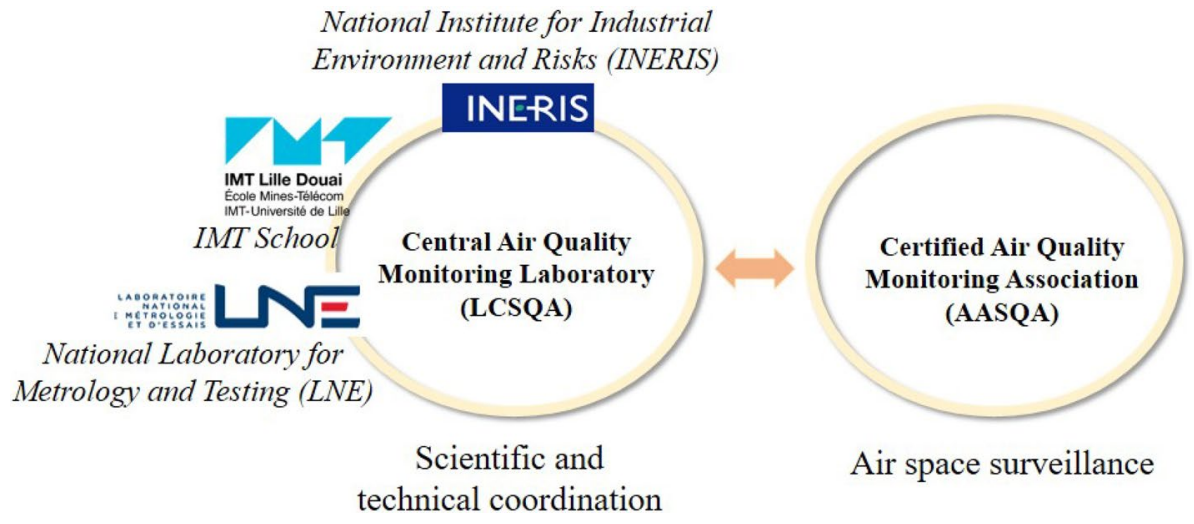

Fig. 1 LCSQA laboratory regulatory partners

186 sampling points belonging to 15 French regions including: Haut-de-France, GrandEst, Île-de-France, Normandy, Brittany, Pays-De-Loire, Centre-Val-De-Loire, Bourgogne Franche-Comté, Nouvelle-Aquitaine, Auvergne Rhône-Alpes, Occitania, Provence AlpesCôte-d'Azur, Corsica, Martinique, and the overseas department Reunion.

\subsection{Collected data}

In this study, we used data of eight pollutants concentrations, namely: Sulphur dioxide $\left(\mathrm{SO}_{2}\right)$, Ozone $\left(\mathrm{O}_{3}\right)$, Nitrogen dioxide $\left(\mathrm{NO}_{2}\right)$, Nitrogen oxides (NOX), Carbon monoxide (CO), Benzene $\left(\mathrm{C}_{6} \mathrm{H}_{6}\right)$, Particulate matter $<2.5 \mu \mathrm{m}$ (aerosol) $\left(\mathrm{PM}_{2.5}\right)$ and Particulate matter $<10 \mu \mathrm{m}$ (aerosol) $\left(\mathrm{PM}_{10}\right)$. This real-time data stream (or UTD data for "Up-To-Date") is conventionally referred to as the "E2 stream". Two mechanisms are adopted to measure and evaluate such data: MERA and CARA. MERA standing for Measurement and Evaluation of long-range air pollution in Rural Areas, consists of 12 measuring stations located all over metropolitan France as depicted in (Fig. 2a), and are intended for the monitoring and characterization of background air pollution found in rural areas. Automatic analysers, air samplers and deposit collectors at each MERA station, have the same operating configuration as in reference measurement methods. Moreover, operational harmonization between stations is achieved through the adoption of ad-hoc procedures to improve the comparability of measurements. When it comes to CARA mechanism standing for "chemical Characterization of particles", this mechanism forms an operational network for realtime observation of the chemical composition of particles, in urban area, using chemical analysis-based filters. (Fig. 2b) illustrates the 12 CARA measuring stations over French territory. For increased visibility of daily pollutant concentrations, we chose to collect daily maximum concentrations values, wherein each given maximum pollutant value was captured at a specific sampling point in a defined French region. The (Fig. 3) shows the daily maximum concentrations values for the eight prominent pollutants, collected within a period extending from January 2020 to July 2020. All concentrations are derived via the data.gouv.fr platform. These pollutants values were more precisely recorded by 164 sampling points spread over the 15 French regions referred above.

On the other hand, we collected from the official website of the French Republic government (Gouvernement 2020), data on the daily active number of coronavirus 


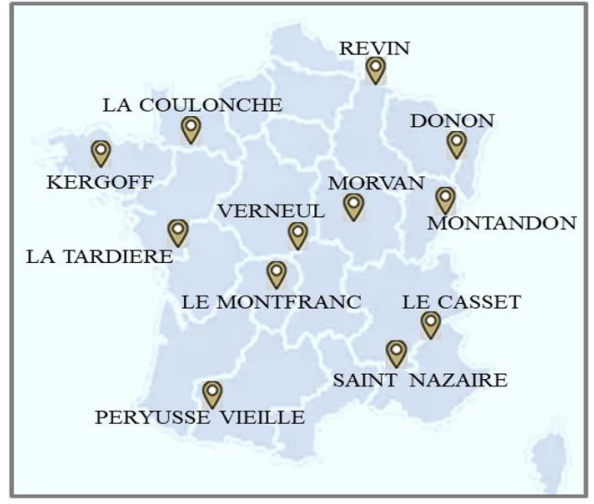

(a) Geographical location of MERA stations in 2020

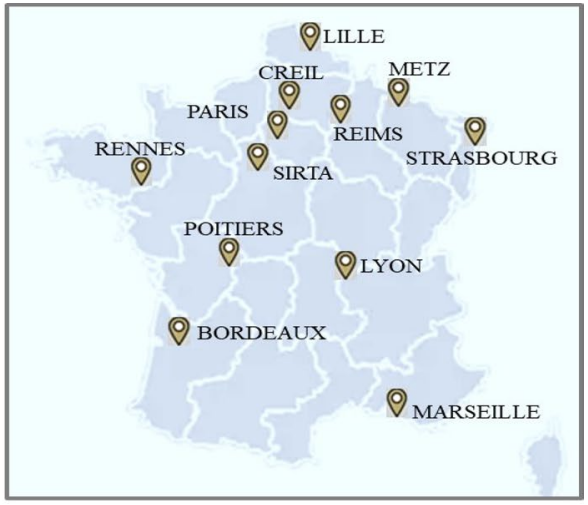

(b) Multi-instrument urban background sites of the CARA programme in 2020

Fig. 2 a MERA measurement mechanism related stations, b CARA measurement mechanism related stations

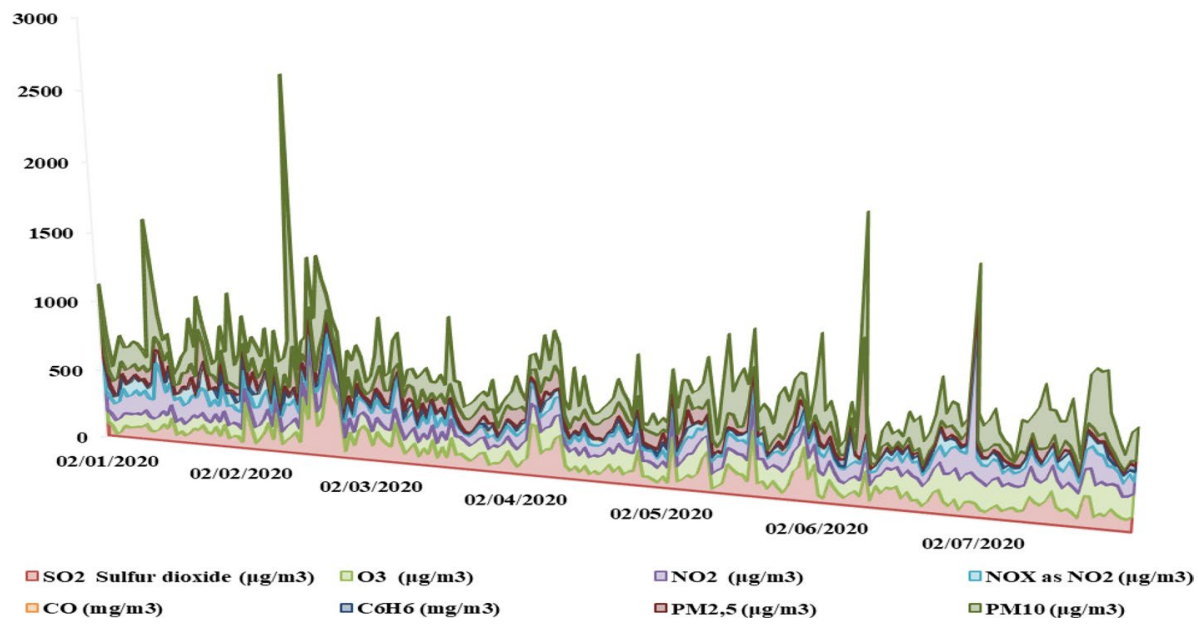

Fig. 3 Maximum daily concentrations of eights pollutants

cases per French region, as mentioned in (Fig. 4) as well as the cumulative death rate for each region, as shown in (Fig. 5). The availability of these data covers a period extending from the start of containment until the end of July 2020. The number of active cases corresponds to the sum of new hospitalized patients, with those in intensive care, other hospitalizations, and patients at home. With regard to confirmed Coronavirus cases by region, the maximum daily active numbers detected during this period are within the Ile-de-France region at first range, at around 13,209. This value is followed by 4993 detected in Grand-Est, 3055 in Auvergne-Rhône-Alpes, 2578 in Haut-De-France, 1909 in Provence, 1380 in Bourgogne Franche-Comté and 1047 in Occitania. The rest of the daily maximum values in other regions were less than 1000 . Over time, the graph in (Fig. 4) depicted a downwards trend of daily active cases. On the other hand, the cumulative mortality rate has not yet really stabilized and keeps 


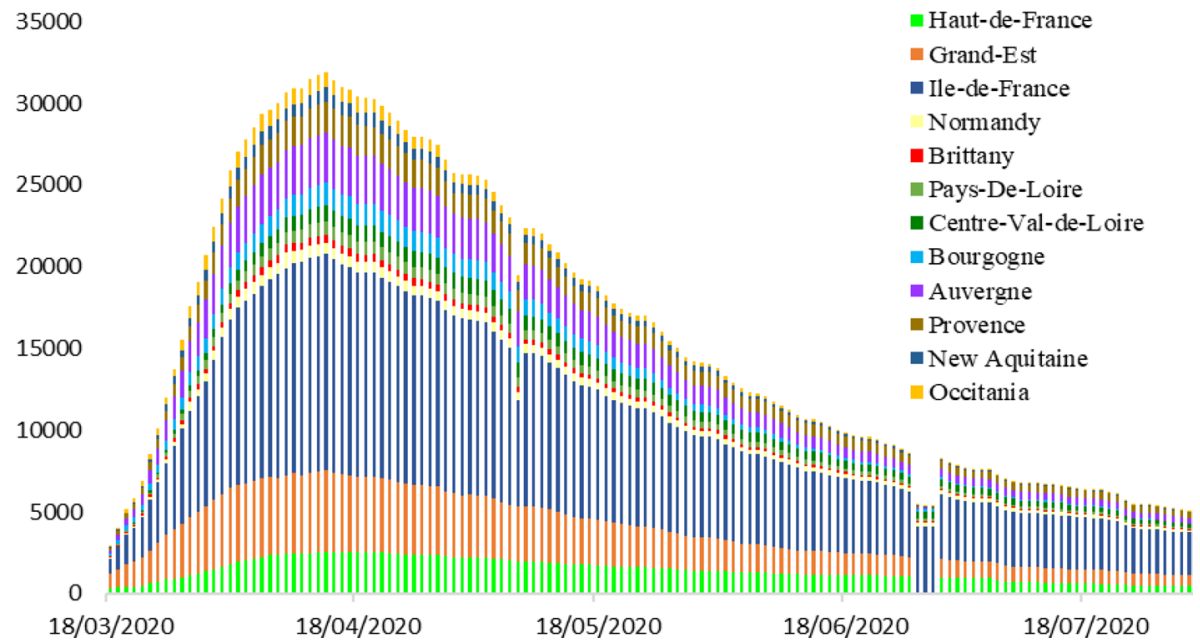

Fig. 4 Active confirmed coronavirus cases per French regions

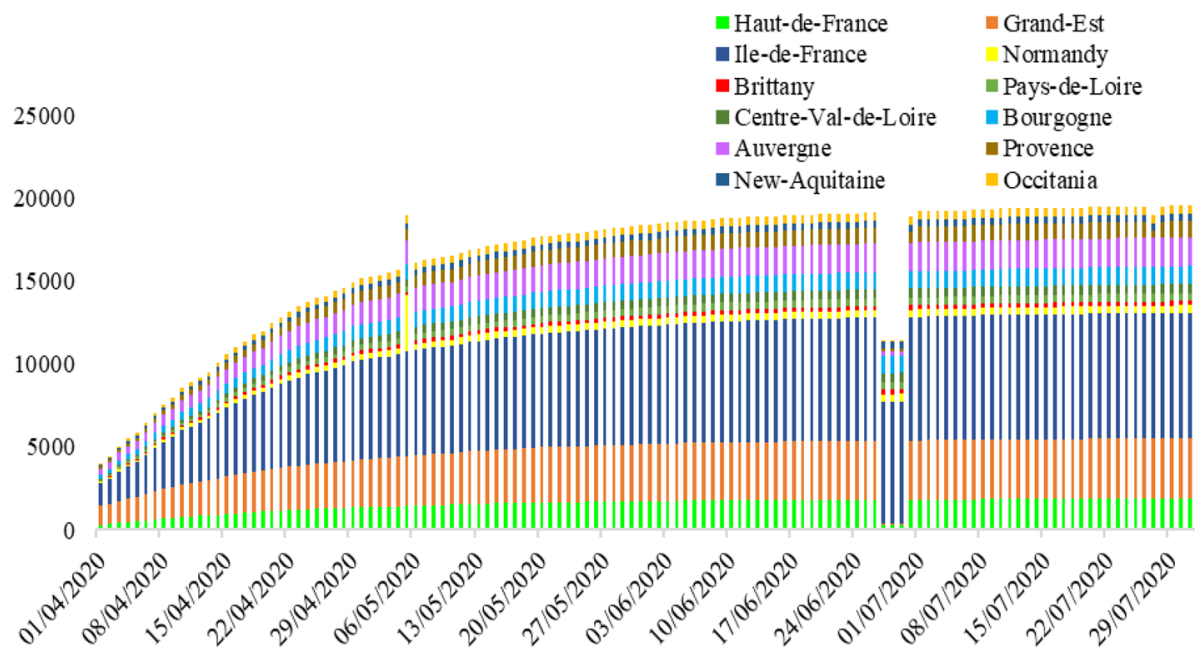

Fig. 5 Cumulative death toll

increasing so far, as indicated in the chart of (Fig. 5). The maximum daily cumulated death tolls, detected over time by region, were in descending order, respectively, as follows: 7569 for the Ile-de-France, 3616 in the Grand-Est, 3363 in Normandy (even with a maximum number of active cases below 1000), 1912 in Haut-de-France, 1760 in Auvergne and 1061 in Bourgogne. All the same, the rest of regions had a maximum mortality rate of less than 1000 . 


\section{Methodologies}

\subsection{Data assessment techniques}

We begin with a variation analysis of maximum concentrations of the main atmospheric pollutants from different French locations, to examine how concentrations have changed throughout the year 2020. Since the considered measurement sites are based on backgrounds of densely populated areas (urban sites) or peri-urban areas, each pollutant was classified according to its urban areas (agglomerations) percentage, from where maximum concentration values were derived. We therefore analyse results according to two air quality assessment indices (ATMO) and (AQI), according to the following classification (LCSQA 2020):

- For pollutants whose maximum values originate predominantly from agglomerations with more than 100,000 habitants, we evaluate results based on the ATMO rating index.

- On the other hand, the AQI ("simplified air quality index") is used for pollutants whose maximum values are predominantly from agglomerations with less than 100,000 habitants.

- There are many other regulated thresholds per country. The official air quality assessment index in France is the ATMO (AirParif 2011). Although it has not changed since some updates made to $\mathrm{PM}_{10}$ index in 2007 , it basically represents a regulatory character in line with European Union directives. It should be noted that it is currently under revision, to be calculated even for agglomerations with less than 100.000 habitants, and to consider concentrations of fine particles $\mathrm{PM}_{2.5}$. The (Fig. 6) below identifies the ATMO (6.a) and AQI (6.b) thresholds per pollutant (Atmo France 2020).

Afterward, we apply multiple correlation technique to study connections between more than two variables at once, which are: daily maximum pollutants concentrations in many regions and the COVID-19 death tolls per region. In fact, it calculates the combined influences of independent variables on a dependent one, with a view on each variable
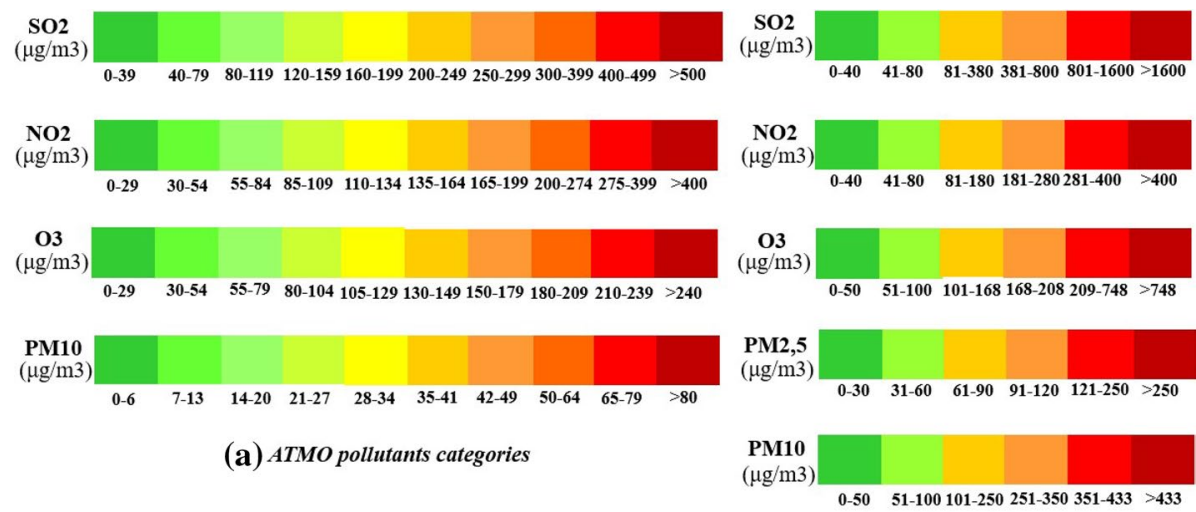

(b) AQI pollutants categories

Fig. 6 Categories of air quality assessment thresholds: ATMO a and AQI b, of different pollutants 
distribution over time space. The independent values in our case are the pollutant concentrations with their related source region, while the dependent variables are the COVID-19 death tolls per many French regions.

\subsection{Near term post lockdown results projection}

The drastic changes the world has experienced in air quality during periods of containment easily spotlights the political attempts and investments made with a view to the hidden climate change crisis. Radical actions, which just five months ago seemed almost inconceivable politically and economically, are today feasible after this pandemic as long as coalition of different interests is reached. By analyzing political and investments perspectives through a weighting study, we intend to project current and near-term future scenarios in the case of French territory. Inspired by three scenarios recently submitted by one of the Business Solution and Innovation Department staff of the French asset management company Amundi (de Bazin 2020), we are interested in projecting post-lockdown results using our main pollutants concentrations analysis, in order to deduce the most plausible scenario. Three possible scenarios, namely the positive, the negative and the status quo were expected along four axes. In our study, we concentrate mainly on the following three axes: policy responses to COVID-19 towards climate change, Actual climate change path, and investment implications. This way, we explore what this pandemic could mean for climate change, along each axis, in the short and medium terms. The (Table 1) below summarizes the significance of each likely scenario along the three axes.

\section{Experiments results and discussion}

\subsection{Changes in concentrations of prominent pollutants in the pre-lockdown, during-lockdown, and post-lockdown periods}

To have a better insight into impacts of each pollutant's daily maximum value, we have classified pollutants according to the AQI and ATMO indices, as it appears in (Fig. 6). The choice of classification index is left to the area's populations, where these daily maximum values were originally gathered. Having said that, for the pollutants $\mathrm{SO}_{2}, \mathrm{O}_{3}$ and $\mathrm{PM}_{2.5}$, most of their sources (sampling points) emerge from municipalities with less than 100,000 residents, thus the selection of AQI classification index (Figs. 7a-c). Besides, areas where the daily maximum values of $\mathrm{NO}_{2}$ and $\mathrm{PM}_{10}$ have been derived, correspond to populations of more than 100,000 habitants, hence the use of ATMO classification index (Fig. 7d, e). From (Fig. 7), we can easily notice how all pollutants have decreased during the containment phase, apart from the ozone pollutant $\mathrm{O}_{3}$ which has risen $27.19 \%$ during this phase, and then it kept growing by $21.35 \%$ as well right after deconfinement. This later finding is primarily due to an unprecedented decrease in the NOX concentrations resulting in a lower $\mathrm{O}_{3}$ titration through Nitrogen (NO) (Sicard et al. 2020). Conversely, the other pollutants' decline was not sustained after deconfinement for pollutants $\mathrm{NO}_{2}$, NOX and $\mathrm{PM}_{10}$. The $\mathrm{NO}_{2}$ pollutant has further increased by $42.32 \%$ over its average in the containment phase. The same applies to the pollutants NOX and $\mathrm{PM}_{10}$, which increased by $15.08 \%$ and $38.15 \%$, respectively, compared to their averages in the containment phase. In addition, the $\mathrm{PM}_{2.5}$ pollutant have increased even worse than their original pre-containment values. For a better 


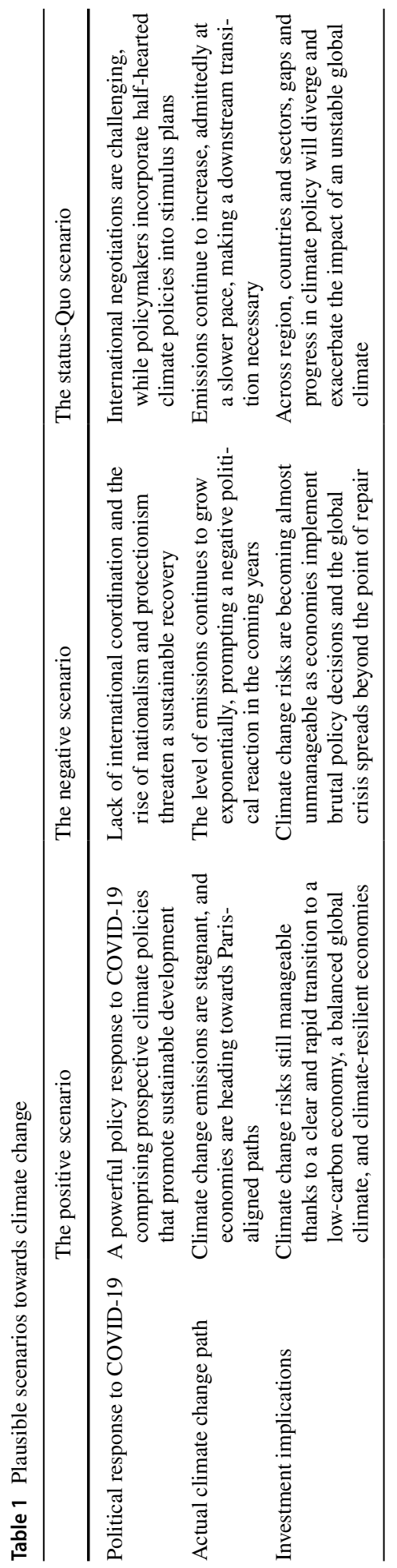




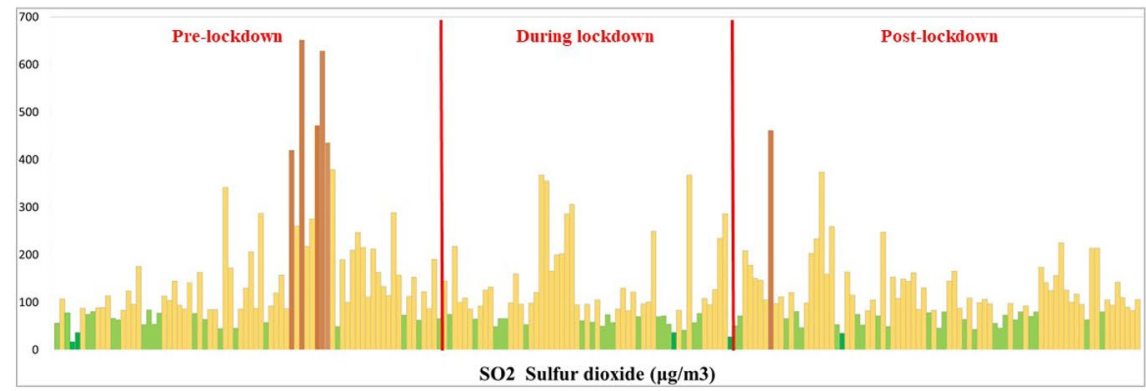

(a) Classification of maximum $\mathrm{SO} 2$ values per $\mathrm{AQI}$ index

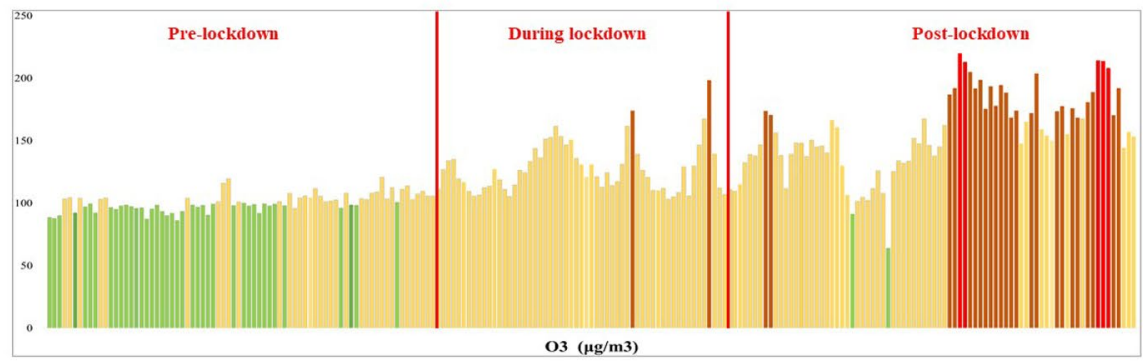

(b) Classification of maximum 03 values per $A Q I$ index

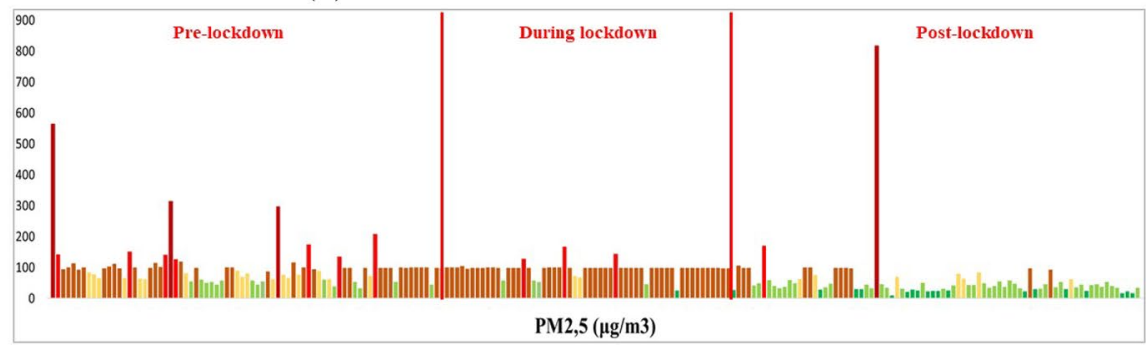

(c) Classification of maximum PM2,5 values per AQI index

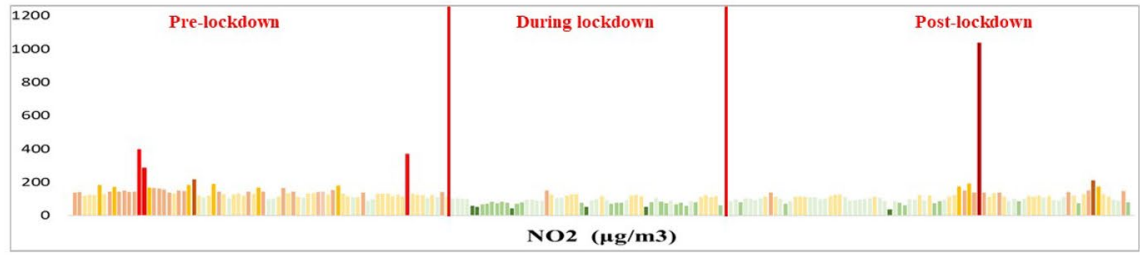

(d) Classification of maximum NO2 values per ATMO index

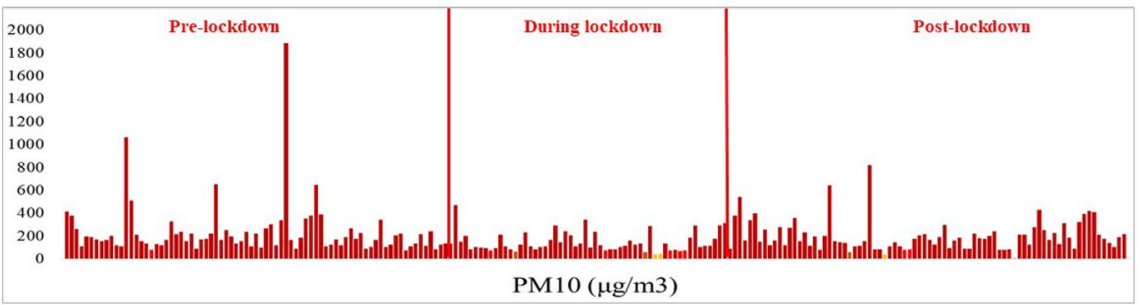

(e) Classification of maximum PM10 values per ATMO index

Fig. 7 Classification of $\mathrm{SO}_{2} \mathbf{a}, \mathrm{O}_{3} \mathbf{b}, \mathrm{PM}_{2.5}$ c pollutants according to AQI index, and $\mathrm{NO}_{2} \mathbf{d}, \mathrm{PM}_{10}$ e according to ATMO index, in Pre/During and Post lockdown periods ranging from 01/01/2020 to 31/07/2020 
visibility on variations established on each pollutant during the three stages of this year, Table 2 reveals some basic statistics related to each pollutant. Subsequently, Table 3 summarizes the percentage changes in the daily maximum concentrations of the eight pollutants, between the pre/during-containment periods, then between the during/post-containment periods.

Moreover, keeping with the aim of highlighting areas responsible for these emissions, we have presented in map charts, French regions englobing sources that have recorded the peak values of these daily maximum pollutants during a period spanning from 1 January 2020 to 13 June 2020, as shown in (Fig. 8). During this period, it should be noted that $\mathrm{SO}_{2}$ concentrations peak values were first recorded in Normandy and then in the "Reunion" region. The peak values of $\mathrm{NO}_{2}$ concentrations were registered in Provence and Pays-De-La-Loire regions. The ozone peaks were concentrated in Normandy and Ile-De-France regions. CO peaks were in Haut-De-France and Provence. $\mathrm{PM}_{2.5}$ peaks were in "New-Aquitaine" and in the French overseas territories. Finally, the $\mathrm{PM}_{10}$ concentration peaks were mainly located in Ile-de-France, NouvelleAquitaine and in Provence regions. Since peak values do not really distinguish regions with high pollution, we were interested in visualizing also the number of occurrences of each pollutant per region. (Fig. 9) illustrates the occurrence numbers of daily maximum $\mathrm{SO}_{2}, \mathrm{NO}_{2}, \mathrm{O}_{3}, \mathrm{CO}, \mathrm{PM}_{2.5}$ and $\mathrm{PM}_{10}$ pollutants values detected per French regions during this same period extending from 01/01/2020 to 13/06/2020.

\subsection{Correlation analysis results}

Given how the rate of hospitalizations contaminated by the Coronavirus are primarily driven by populations, we merely interested to understand correlations between each pollutant concentration and the related COVID-19 death rates per region. These correlations are clearly depicted in the last horizontal and vertical axes of Figs. 10a, f, 11b-e. As can be seen from the diagonals of the (Fig. 10) charts, the whole considered variables have almost normal distributions. The available data, on which we based this coherence study, represent a sample of a time interval between 01/04/2020 and 13/06/2020. Thanks to this coherence study, we have highlighted some major correlations between each daily maximum pollutants concentrations gathered from various French regions and the cumulative dailies mortality rates of all French regions, as shown in red in each single chart. For instance, one notices in Fig. 10a the influence of $\mathrm{SO}_{2}$ on death rate in Normandy and New-Aquitaine regions, as well as the approximate influence of $\mathrm{O}_{3}$ on death toll in Provence region, from Fig. 10b. In addition, we have again emphasized a correlation between $\mathrm{NO}_{2}$ and mortality rates in Normandy from Fig. 10c. Then, the influence of carbon monoxide $(\mathrm{CO})$ has been strongly noticed from Fig. 10d, on mortality rates in Haut-De-France and Ile-De-France regions. Finally, we notice, respectively, from Figs. 10e, f, $\mathrm{PM}_{2.5}$ influences on death rates in Auvergne and Occitania regions and $\mathrm{PM}_{10}$ influences on death rates in Auvergne, Haut de France, Provence and New-Aquitaine.

In short, we have roughly detected this great coherence in the cases of aerosols and Carbon monoxide pollutants. We come to the conclusion that air pollutants concentrations remain approximately influential on mortality rates, although such mortality rates are firstly attributable to some key determinants as living environment, antecedent health state and obviously the decay rate of virus detection. 


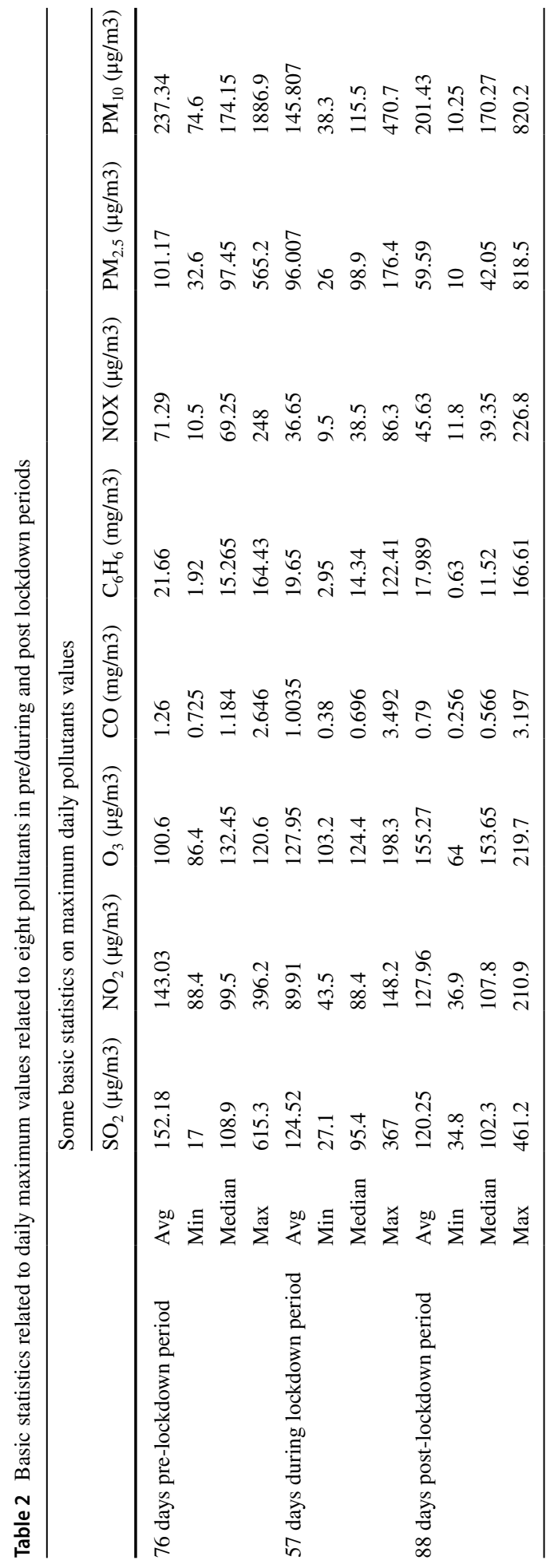


Table 3 Percentage variations of eights daily maximum values pollutants between pre/during lockdown and during/post lockdown periods

\begin{tabular}{lllll}
\hline Pollutants & $\begin{array}{l}\text { Variation between pre } \\
\text { and during lockdown } \\
\text { values }\end{array}$ & Variation percentage & $\begin{array}{l}\text { Variation between } \\
\text { during and post lock- } \\
\text { down values }\end{array}$ & Variation percentage \\
\hline $\mathrm{SO}_{2}$ & -27.66 & A decrease of $18.18 \%$ & -4.27 & A decrease of $3.4 \%$ \\
$\mathrm{NO}_{2}$ & -53.12 & A decrease of $37.14 \%$ & 38.05 & An increase of $42.32 \%$ \\
$\mathrm{O}_{3}$ & 27.35 & $\begin{array}{l}\text { An increase of } \\
27.19 \%\end{array}$ & 27.32 & An increase of $21.35 \%$ \\
$\mathrm{CO}$ & -2.26 & A decrease of $20.36 \%$ & -0.214 & A decrease of $21.28 \%$ \\
$\mathrm{C}_{6} \mathrm{H}_{6}$ & -2.01 & A decrease of $9.28 \%$ & -1.66 & A decrease of $8.45 \%$ \\
$\mathrm{NOX}$ & -31.64 & A decrease of $44,38 \%$ & 5.98 & An increase of $15.08 \%$ \\
$\mathrm{PM}_{2.5}$ & -5.163 & A decrease of $5.1 \%$ & -36.42 & A decrease of $37.93 \%$ \\
$\mathrm{PM}_{10}$ & -91.533 & A decrease of $38.57 \%$ & 55.623 & An increase of $38.15 \%$ \\
\hline
\end{tabular}

\subsection{Post lockdown results projection}

In a warming world, the risks of infectious diseases like the current case of coronavirus are likely to increase rapidly, as long as disease-carrying parasites spread more quickly. The climate crisis may not yet be as visible, as COVID-19, however coping with it urgently is also conducive to disaster prevention. A valuable lesson from this pandemic: recognizing a problem as a crisis, tend to embrace and accept extraordinary measures. The drastic actions took by both Republican and Democratic governors, numerous businesses and individuals have been utterly unimaginable just six months earlier. Now that countries are lifting their lockdowns, and economies are gradually rebounding, the marked improvement in air quality achieved during the past confinement phases will not persist. While the pandemic would be nearly overcome with the help of a vaccine, what will be then the future climate crisis vaccine?

Ongoing researches are looking into post-COVID-19 stimulus package, what weight would climate change contribute then in these recovery plans? Arguably, actions towards climate change should be launched from now, through managing competing interests and giving priority to different constituencies. That is, a synergy must be found between the following four key points (Bernauer and Slowey 2020): Community health, environment protection, economic benefits and indigenous rights. According to a former president, and CEO World Environment Center (Yosie 2020), bending climate curve is underpinned first by a policy striving towards any fossil fuels reduction, then by multinational investors boosting their international commitments towards the net-zero carbon emissions by 2050 .

Among guides reshaping the climate recovery curve, (Barbier and Burgess 2020) argues three policies yield immediate progress towards several Sustainable Development Goals (SDG): a fossil fuel subsidy swap to fund clean energy investments and dissemination of renewable energy in rural areas; reallocating irrigation subsidies to improve water supply and wastewater infrastructure; and a tropical carbon tax to fund natural climate solutions. Climate resilient recovery is another key guide manifested through smart economies. According to the Global Commission on Adaptation (United Nations Climate Change 2020), we need to invest in durable and adaptive economic activities protecting communities and natural ecosystems. Adaptation often creates more jobs per dollar spent than more traditional investment, with superior local benefits. 


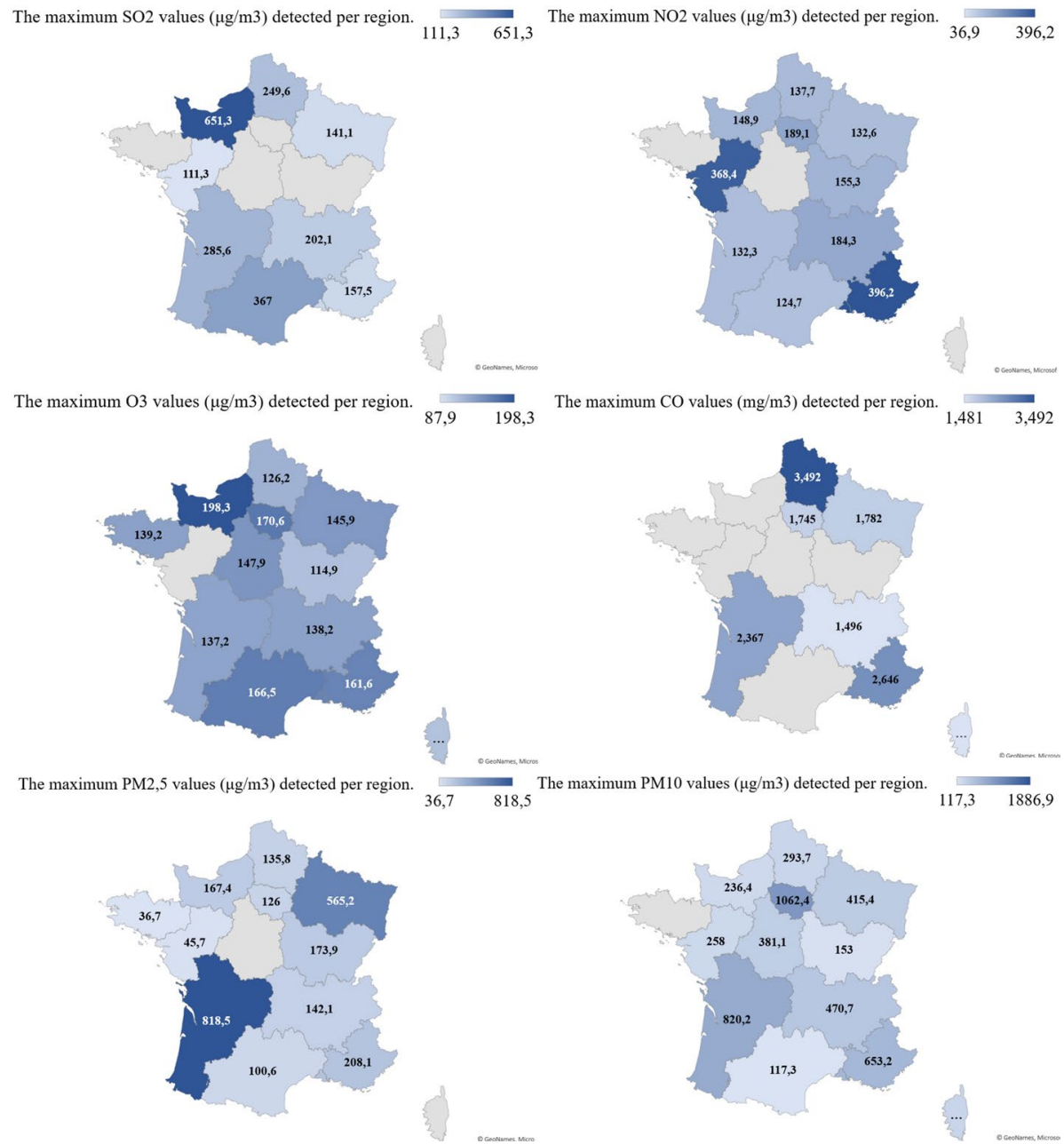

Fig. 8 The peak of daily maximum pollutants values of the $\mathrm{SO}_{2}, \mathrm{NO}_{2}, \mathrm{O}_{3}, \mathrm{CO}, \mathrm{PM}_{2.5}$ and $\mathrm{PM}_{10}$ detected per French regions during a period ranging from 01/01/2020 to 13/06/2020

Then along with boosted resilience, international cooperation is essential in global challenge (Guinto 2020). The social psychologist Stephen Reicher said: "when faced with a crisis, coming together is the one vehicle of change humans have when it comes to fighting for their future". According to (United Nations Climate Change 2020), the United State (US) administration's intention to withdraw from the Paris Climate Accord in 2017 , their refusal to participate in the global initiative on the development, production and distribution of COVID-19 vaccines, is not a good sign of good integration and cooperation. What COVID-19 broadly revealed were the disastrous consequences of ignoring every warning, a lesson ought to be exploited to achieve better integration. The United Nations Climate Change Conference (COP26), which has been postponed to 2021, is raising the likelihood of the US being represented at the COP with a more positive stance on climate change (Kuzemko et al. 2020). But how far along are other countries' efforts? 


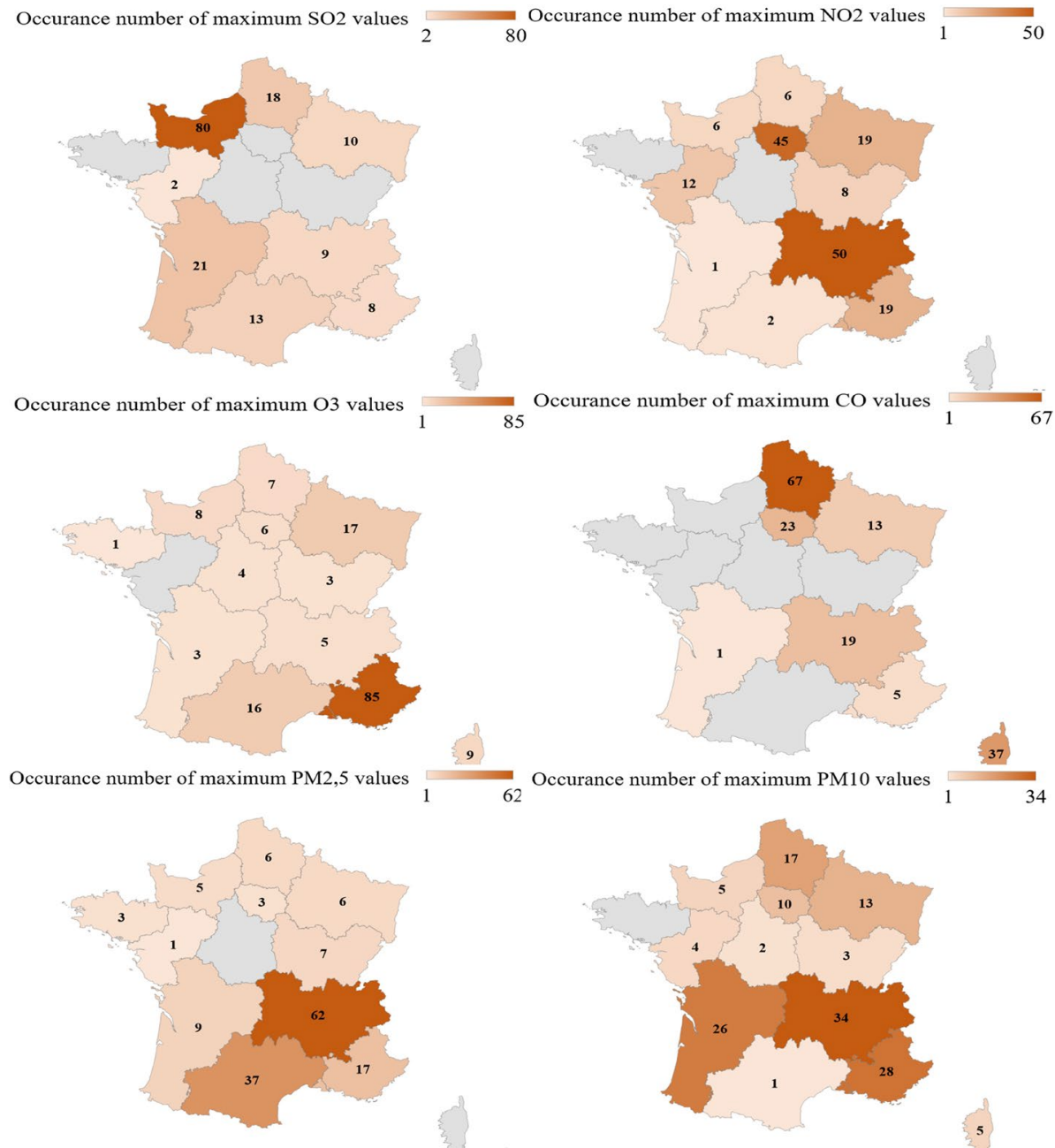

Fig. 9 The occurrence number of daily maximum $\mathrm{SO}_{2}, \mathrm{NO}_{2}, \mathrm{O}_{3}, \mathrm{CO}, \mathrm{PM}_{2.5}$ and $\mathrm{PM}_{10}$ pollutants values detected per French regions during a period ranging from 01/01/2020 to 13/06/2020

Above all, as an adequate response to the impending climate disaster, the European Union must align all post-pandemic recovery actions beyond the more ambitious 1.5-degree target of the Paris agreement (Hägele and Mathis, 2020). Towards this reason, the new European Green Deal (EUGreenDeal) (Montanarella and Panagos 2020) offers a chance for the European Union to reach the first climate-neutral continent by 2050. Hopefully, we are already beginning to see a glimmer of bright through the ten European Union countries' call for the use of recovery plans to support the European "Green Deal" for climate neutrality by 2050 (Thomas 2020). The IEA warns that the 2020 drop in emissions would be triggered by a huge increase unless stimulus packages emphasize a low-carbon, decarbonizing recovery (Sustainable Recovery - Analysis-IEA 2020). To rethink infrastructure, the United Kingdom plans to spend 250 million pounds of its stimulus package on walking and cycling infrastructure. Japan's integrated solutions prove that the response 


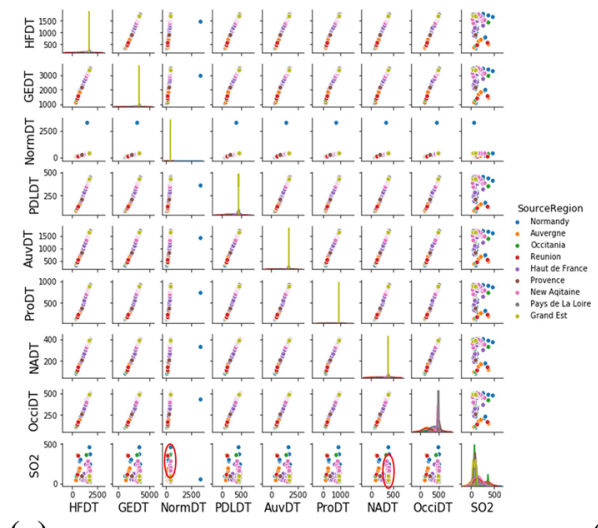

(a) Correlation between $\mathrm{SO} 2$ concentrations per region and death toll by region

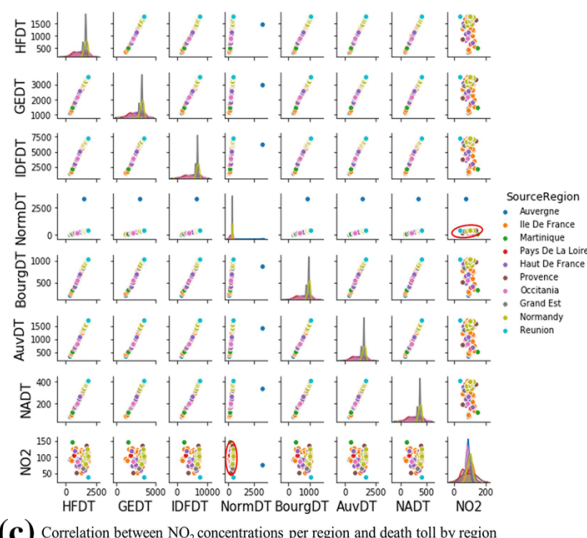

(c) Correlation between $\mathrm{NO}_{2}$ concentrations per region and death toll by region

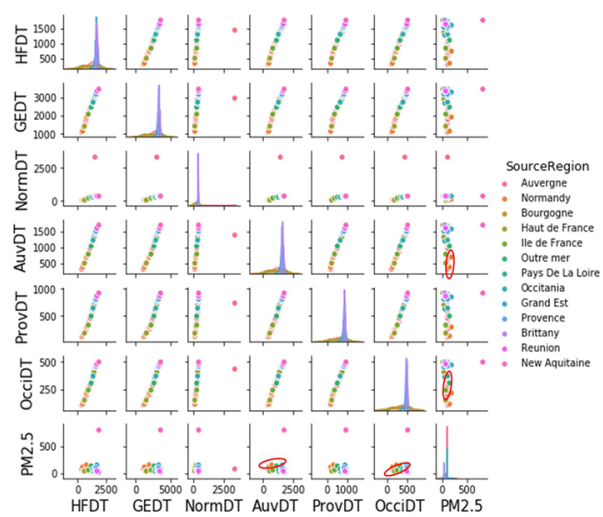

(e) Correlation between PM2,5 concentrations per region and
death toll by region

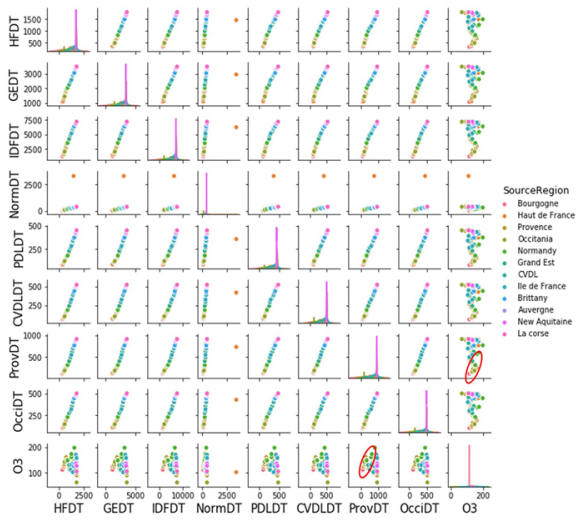

(b) Correlation between 03 concentrations per region and death toll by region

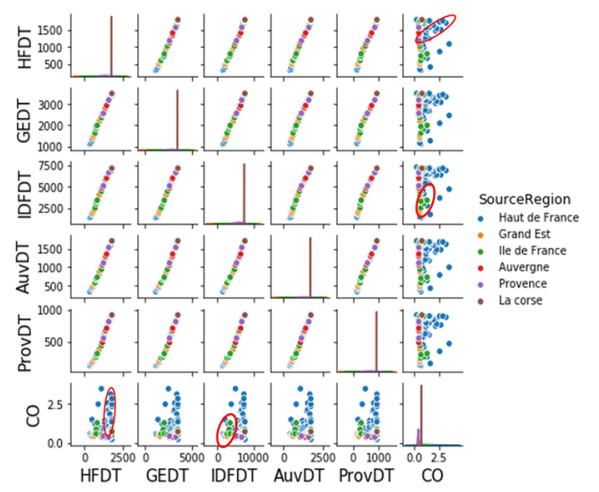

(d) Correlation between $\mathrm{CO}$ concentrations per region and death

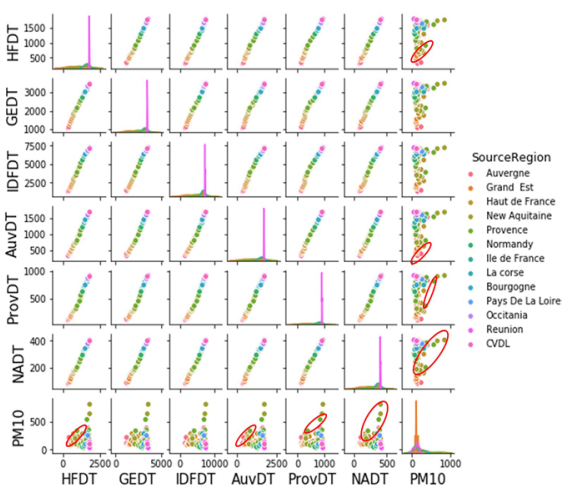

(f) Correlation between Particulate Matter (PM10) concentrations per region and death toll by region

Fig. 10 Correlations between six daily maximum pollutants concentrations and death tolls per regions

to a pandemic is not just about accelerated decarbonization, but also about sustainable and resilient development (DeWit et al. 2020). Many criticized the exaggerated size of Japan's fiscal stimulus on April 7, which stands at JPY 108 trillion. But this wide-ranging 
Fig. 11 The plausible current and near-term French scenario

\section{AFrench Political Responses $\quad \approx$ Actual French Climate Path \\ French Investments Implications}

Good

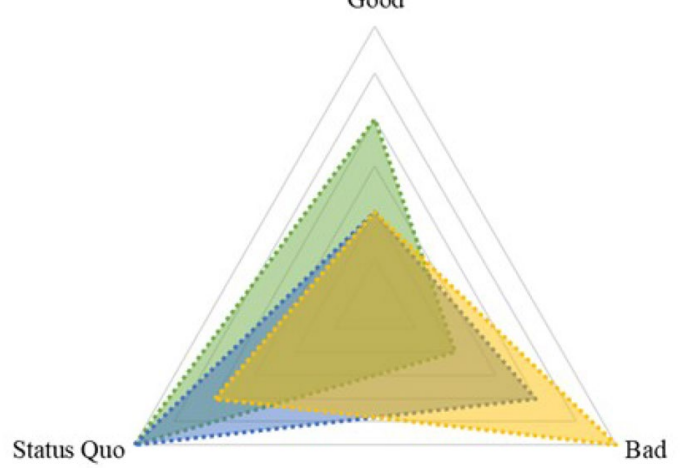

assessment diverted attention to the strong resilience-focused content of the previous year's stimulus, which had nothing to do with COVID-19, but rather responded to Japan's need to strengthen overall disaster resilience (DeWit et al. 2020).

To frame a French case study, the pathway for reducing air pollutant concentrations during the containment phase, as demonstrated in (Sect. 4.1), did not persist immediately afterwards for the main pollutants $\left(\mathrm{NO}_{2}\right.$, NOX and $\left.\mathrm{PM}_{10}\right)$. However, this downwards trajectory has been well noted for other pollutants $\mathrm{SO}_{2}, \mathrm{CO}, \mathrm{C}_{6} \mathrm{H}_{6}$ and $\mathrm{PM}_{2.5}$ (Table 3), and it is therefore time to exploit the relatively cleaner air that the pandemic has left. For this, more concise political are arrogantly calculated in light of climate change. According to the French Ministry of Ecological Transition (Ministère de La Transition Écologique 2020), the new version of the National Low-Carbon Strategy (SNBC) and the carbon budgets for the periods 2019-2923, 2024-2028 and 2029-2033 were adopted by decree on 21 April 2020. France is among countries that have decided to reconceptualize infrastructure, industry, energy, and government to reduce emissions contributing to climate change. First, France was among country recognizing recycling sector as an essential sector, this is evidenced by the permanent opening of French recycling units throughout the crisis (Sharma et al. 2020a, b). Furthermore, as transportation is one of the largest sources of greenhouse gas emissions in the world, the extension of Bike' infrastructure has started from Paris and spread to other French cities (Umair Irfan 2020), to offer vehicles' alternatives. However, since several intentions to bail out the aviation and fossil fuel sectors will significantly contribute to increasing pollution (Hägele and Mathis 2020), the French gouvernement used even their leverage with bailouts to push for stronger climate commitments from companies. For example, the $\$ 10.8$ billion rescue package for Air France-KLM included provisions that Air France was to end short routes that compete with rail routes (Irfan 2020). The reason is that rail travel emits far less greenhouse gases than flying on these short routes. The airline will also have to halve its emissions per passenger compared to 2005 by 2050 , for example state aid was granted to Air France on condition to reduce its domestic flights by $40 \%$ by 2021 (Budd and Ison 2020). However, for resilience such as that mentioned above in the case of Japan, policy needs to be strengthened and supported by corporate commitment and individual responsibilities (Budd and Ison 2020). As an example of corporate commitment: Shell Oil Company's April 16 declaration to become a net-zero emissions 
energy company by 2050 was followed shortly afterwards by a similar announcement by the French oil giant Total. Arnaud Leroy: President of Ademe (Agence de La Transition Écologique-ADEME 2020), recently announced a new signature and new projects signed in mid-June 2020 to become the Agency for Ecological Transition, starting from this post-COVID period. Then as an instance of individual responsibility, during the presentation of the plan to revive the French automobile industry, private individuals choose to install electrical terminals in their car parks, even in condominiums (Romain 2020). To get around this problem, some operators propose to install, at their own expense, their own electricity meter in the building's parking lot (Romain 2020). Such personal investments are a real support for governments, as the economic plight of the world today cannot be denied. On April 18, the International Monetary Fund (IMF) had already estimated the total cost of the pandemic for 2020-2021 would be \$9 trillion, roughly equivalent to the joint size of the German and Japanese economies (DeWit et al. 2020). François Villeroy de Galhau, governor of Banque de France (Galhau 2020) said: it's critical that countries launch a green recovery from the pandemic. France spent $19 \%$ of its GDP percentage for a recovery plan, which amounts to 425 billion euros (DeWit et al. 2020). Such rating may underline an overview of the economic crisis repercussions generated by Post-COVID-19 on current investment in French regions. To conclude and summarize the current and very short-term situation of the above (Environmental, political, and economic) axes related to French territory, we have deduced, thanks to a weighting study, the most plausible current scenario. (Fig. 11) highlights the current and short-term scenario facing the French territory: The Status-Quo.

\section{Conclusion}

To conclude, this study roughly provides an analysis over Amid-COVID19 implications regarding variations of some major pollutants' concentrations in the whole French regions, during three lockdown phases: pre/during and post periods. The findings are not as relieving, seeing the continuous increase in Ozone concentrations during the 3 periods, then considering the main reductions did not persist for $\mathrm{NO}_{2}, \mathrm{NOX}$ and $\mathrm{PM}_{10}$ pollutants just after deconfinement. In a second sense, we have outlined the influences that these pollutants have on some French regions' mortality rates. Subsequently, such equivocal influences found in these two analyses prompted the need to track some current political and economic French alternatives towards the future climate change crisis. From which we concluded hence, the France actual and near-term position, which is neither in the positive nor the negative scenario, but rather in a Status-Quo stage. That further said, in order to stagnate the increases of Post COVID-19 atmospheric pollutants concentrations and ensure they are continuously reduced, a thorough stimulus plan including green and sustainable measures needs to be meticulously established in favour of a greener climate, despite the severe global economic crisis sparked by this pandemic.

Acknowledgements We are incredibly grateful to the anonymous reviewers for their valuable comments on this paper.

\section{Compliance with ethical standards}

Conflict of interest No potential conflict of interest was reported by the author(s). 


\section{References}

Agence de la transition écologique - ADEME. (2020). https://www.ademe.fr/

AirParif. (2011). International comparison of air quality monitoring systems.

Atmo France - Réseau national des Associations agréées de surveillance de la qualité de l'air. (2020). Retrieved August 11, 2020, from https://atmo-france.org/

Barbier, E. B., \& Burgess, J. C. (2020). Sustainability and development after COVID-19. In World Development (Vol. 135, p. 105082). Elsevier, Amsterdam. https://doi.org/10.1016/j.worlddev.2020.105082

Bernauer, W., \& Slowey, G. (2020). COVID-19, extractive industries, and indigenous communities in Canada: Notes towards a political economy research agenda. In Extractive Industries and Society. Elsevier, Amsterdam. https://doi.org/10.1016/j.exis.2020.05.012

Budd, L., \& Ison, S. (2020). Responsible Transport: A post-COVID agenda for transport policy and practice. Transportation Research Interdisciplinary Perspectives, 6, 100151. https://doi.org/10.1016/j. trip.2020.100151.

Chow, D. (2020) Carbon emissions dropped 17 percent globally amid coronavirus. Retrieved August 7, 2020, from https://www.nbcnews.com/science/environment/carbon-emissions-dropped-17-percentglobally-amid-coronavirus-n1210331

cop - La COP21 sur le climat (définition, enjeu, résumé). L'accord de Paris|Agence Parisienne du Climat. (2018). Retrieved August 6, 2020, from https://www.apc-paris.com/cop-21

Coronavirus Update (Live): 18,839,429 Cases and 707,239 Deaths from COVID-19 Virus Pandemic - Worldometer. (2020). Retrieved August 5, 2020, from https://www.worldometers.info/coronavirus/?utm_ campaign=homeAdvegas $1 ? \% 22 \% 5 \mathrm{Cl} \% 22$ countries

Dantas, G., Siciliano, B., França, B. B., da Silva, C. M., \& Arbilla, G. (2020). The impact of COVID-19 partial lockdown on the air quality of the city of Rio de Janeiro Brazil. Science of the Total Environment, 729, 139085. https://doi.org/10.1016/j.scitotenv.2020.139085.

de Bazin, A., Hessenberger, T., Pouget Abadie, T., (2020, 16 june). The day after \#7 - Climate change post COVID-19: A crisis at a crossroad / 06 / 2020 / Article / Research Center. (2020, June 10). https://resea rch-center.amundi.com/page/Article/2020/06/The-day-after-7-Climate-change-postCOVID-19-A-crisi s-at-a-crossroad

DeWit, A., Shaw, R., \& Djalante, R. (2020). An integrated approach to sustainable development, National Resilience, and COVID-19 responses: The case of Japan. International Journal of Disaster Risk Reduction, 51, 101808. https://doi.org/10.1016/j.ijdrr.2020.101808.

de Perthuis, C., \& Trotignon, R. (2015). COP21: quelles chances de succès? Politique Étrangère, Été, $2,83$. https://doi.org/10.3917/pe.152.0083.

Fabert, P. (2016). COP21 Enseignements des ateliers de mobilisation de l'expertise.

Fareed, Z., Iqbal, N., Shahzad, F., Shah, S. G. M., Zulfiqar, B., Shahzad, K., Hashmi, S. H., \& Shahzad, U. (2020). Co-variance nexus between COVID-19 mortality, humidity, and air quality index in Wuhan, China: New insights from partial and multiple wavelet coherence. In Air Quality, Atmosphere and Health (Vol. 13, Issue 6, pp. 673-682). Springer, Berlin. https://doi.org/10.1007/s11869-020-00847-1

Furfali, S., (2020). Du Succès Diplomatique de La COP21 Aux Échecs Des COP... I (Connaissances Des Énergies). Retrieved August 7, 2020, from https://www.connaissancedesenergies.org/tribune-actualiteenergies/du-succes-diplomatique-dela-cop21-aux-echecs-des-cop

Galhau, F. V. de. (2020). François Villeroy de Galhau: Monetary policy in the face of the COVID crisis. https://www.bis.org/review/r200526a.htm

Gouvernement. (2020). info coronavirus COVID 19 - carte et donnees COVID 19 en france I Gouvernement. fr. Retrieved August 21, 2020, from https://www.gouvernement.fr/info-coronavirus/carte-et-donnees

Hägele, R., \& Mathis, O. Lou. (2020). From COVID-19 to climate action The Current Column. www.diegdi.de

Ipsos Mori (2020). How does the world view climate change and COVID-19?

Kuzemko, C., Bradshaw, M., Bridge, G., Goldthau, A., Jewell, J., Overland, I., Scholten, D., Van de Graaf, T., \& Westphal, K. (2020). COVID-19 and the politics of sustainable energy transitions. In Energy Research and Social Science (Vol. 68, p. 101685). Elsevier, Amsterdam. https://doi.org/10.1016/j. erss.2020.101685

LCSQA. Indices de la qualité de l'air (2020). Retrieved August 11, 2020, from https://www.lcsqa.org/fr/ indices-qualite-air

Mahato, S., Pal, S., \& Ghosh, K. G. (2020). Effect of lockdown amid COVID-19 pandemic on air quality of the megacity Delhi, India. Science of the Total Environment, 730, 139086. https://doi.org/10.1016/j. scitotenv.2020.139086.

Manzanedo, R. D., \& Manning, P. (2020). COVID-19: Lessons for the climate change emergency. Science of the Total Environment, 742, 140563. https://doi.org/10.1016/j.scitotenv.2020.140563. 
Ministère de la Transition écologique. (2020). Stratégie Nationale Bas-Carbone (SNBC). Retrieved August 23, 2020, from https://www.ecologie.gouv.fr/strategie-nationale-bas-carbone-snbc

Montanarella, L., \& Panagos, P. (2020). The relevance of sustainable soil management within the European Green Deal. Land Use Policy, 100, 104950. https://doi.org/10.1016/j.landusepol.2020.104950.

Pansini, R., \& Fornacca, D. (9999). COVID-19 higher induced mortality in Chinese regions with lower air quality.

Pernot Romain. (2020). Installer une borne électrique en copropriété, c'est possible ! https://www.actuenvironnement.com/ae/news/borne-electrique-zeplug-35885.php4\#xtor=ES-6

Pramanik, M., Udmale, P., Bisht, P., Chowdhury, K., Szabo, S., \& Pal, I. (2020). Climatic factors influence the spread of COVID-19 in Russia. International Journal of Environmental Health Research. https:// doi.org/10.1080/09603123.2020.1793921.

Renzo Guinto. (2020, August 4). The response to COVID-19 must protect the planet I World Economic Forum. https://www.weforum.org/agenda/2020/08/pandemic-policy-must-be-climate-policy/

Rosenbloom, D., \& Markard, J. (2020). A COVID-19 recovery for climate. In Science (Vol. 368, Issue 6490, p. 447). American Association for the Advancement of Science. https://doi.org/10.1126/SCIEN CE.ABC4887

Sharma, H. B., Vanapalli, K. R., Cheela, V. S., Ranjan, V. P., Jaglan, A. K., Dubey, B., et al. (2020a). Challenges, opportunities, and innovations for effective solid waste management during and post COVID19 pandemic. Resources, Conservation and Recycling, 162, 105052. https://doi.org/10.1016/j.resco nrec.2020.105052.

Sharma, S., Zhang, M., Anshika, G. J., Zhang, H., \& Kota, S. H. (2020b). Effect of restricted emissions during COVID-19 on air quality in India. Science of the Total Environment, 728, 138878. https://doi. org/10.1016/j.scitotenv.2020.138878.

Sicard, P., De Marco, A., Agathokleous, E., Feng, Z., Xu, X., Paoletti, E., et al. (2020). Amplified ozone pollution in cities during the COVID-19 lockdown. Science of the Total Environment, 735, 139542. https://doi.org/10.1016/j.scitotenv.2020.139542.

Skah, M. (2018). PP-18/13 De la COP21 à la COP24 : bilan d'étape Policy Paper.

Sustainable Recovery - Analysis - IEA. (2020). Retrieved August 23, 2020, from https://www.iea.org/repor ts/sustainable-recovery

Tammineni, Y., Dakuri, T., \& Sailesh, S. (2020). COVID-19: A boon for environment. International Journal of Advanced Research, 8(6), 455-462. https://doi.org/10.21474/IJAR01/11119.

Terry F.Yosie. (2020). How COVID-19 can shape the response to climate change I Greenbiz. https://www. greenbiz.com/article/how-COVID-19-can-shape-response-climate-change

Umair Irfan. (2020, June 8). COVID-19 in South Korea, France, and Italy: using the response to fight climate change - Vox. https://www.vox.com/2020/6/4/21276805/coronavirus-south-korea-france-italy -COVID-19-stimulus-climate-change

United Nations Climate Change. (2020, July 9). Call to Action for a Climate-Resilient Recovery from COVID-19 | UNFCCC. https://unfccc.int/news/call-to-action-for-a-climate-resilient-recovery-fromCOVID-19

Vinod Thomas. (2020). Climate change merits a fiscal response like COVID-19's. https://www.brookings. edu/blog/future-development/2020/06/24/climate-change-merits-a-fiscal-response-like-COVID-19s/

Wang, B., Liu, J., Fu, S., Xu, X., Li, L., Ma, Y., Zhou, J., Yao, J., Liu, X., Zhang, X., He, X., Yan, J., Shi, Y., Ren, X., Niu, J., Luo, B., \& Zhang, K. (2020). An effect assessment of Airborne particulate matter pollution on COVID-19: A multi-city Study in China. MedRxiv, 2020.04.09.20060137. https://doi. org/10.1101/2020.04.09.20060137

World Health Organization. (2015). Climate and health country profile - France. United Nations Framework Convention on Climate Change, 2015(2014), 1-8. https://www.who.int/globalchange/en/

Worldometer. (2020). Coronavirus Cases. Worldometer. https://doi.org/10.1101/2020.01.23.20018549V2.

Zoran, M. A., Savastru, R. S., Savastru, D. M., \& Tautan, M. N. (2020). Assessing the relationship between surface levels of $\mathrm{PM}_{2.5}$ and $\mathrm{PM}_{10}$ particulate matter impact on COVID-19 in Milan. Italy. Science of the Total Environment, 738, 139825. https://doi.org/10.1016/j.scitotenv.2020.139825.

Publisher's Note Springer Nature remains neutral with regard to jurisdictional claims in published maps and institutional affiliations. 


\section{Authors and Affiliations}

\section{Hamzaoui Ikhlasse $e^{1,2,3}$ - Duthil Benjamin ${ }^{3,4} \cdot$ Courboulay Vincent ${ }^{4}$. Medromi Hicham ${ }^{1,2}$}

1 Research Foundation for Development and Innovation in Science and Engineering, 16469 Casablanca, Morocco

2 Engineering Research Laboratory (LRI), System Architecture Team (EAS), National and High School of Electricity and Mechanic (ENSEM), Hassan II University, 8118 Casablanca, Morocco

3 EIGSI, La Rochelle, France

4 Computer, Image and Interaction Laboratory (L3i), University of La Rochelle, La Rochelle, France 